\title{
Views on treatment adherence among psychoactive substance-dependent women in the outpatient setting: a qualitative study
}

\author{
Significados atribuídos por mulheres dependentes de substâncias psicoativas à \\ adesão ao tratamento no contexto ambulatorial: um estudo qualitativo
}

Dione Viégas Almeida Ribeiro, ${ }^{1}$ Egberto Ribeiro Turato, ${ }^{2}$ Renata Cruz Soares de Azevedo, ${ }^{3}$ Claudinei José Gomes Campos ${ }^{4}$

\begin{abstract}
Introduction: In the female population, adherence to specialist clinical treatment for psychoactive substance dependence has peculiar characteristics in terms of therapeutic approaches available to addicts in general. A smaller number of women seek specialist treatment in comparison with men. Traditionally, most health care services specializing in chemical dependence provide similar therapies to both men or women, including the use of mixed-sex groups at some facilities. Objective: To discuss the views or psychological meanings attributed by women with substance use disorders to phenomena associated with adherence to treatment at a specialist university outpatient clinic.

Methods: The qualitative-clinical method was used, i.e., an approach characterized by the typically qualitative focus of human sciences adapted to health care settings. The semi-structured interview technique with open questions was used for data collection, combined with observation of the women interviewed. Data were processed using qualitative content analysis.

Results: Three categories of treatment outcomes emerged: 1) significant motivations to seek and follow the treatment proposed; 2) symbolic meanings attributed to the drug; 3) psychological representations of lack of motivation to explain difficulties adhering to treatment.

Conclusions: Our findings suggest that the motivations of addicted women to seek treatment vary, but highlight the fact that the substance used becomes perceived as something that causes significant losses and hinders the proper exercise of women's role in family and social contexts. A warm welcoming is considered essential for a patient to adhere to treatment, offsetting the strong physical pleasure associated with psychoactive substance use.

Keywords: Qualitative research, patient dropout, women's health services, women's health, substance-related disorders, patient compliance.
\end{abstract}

Resumo

Introdução: Na população feminina, a adesão a tratamentos clínicos especializados em dependência de substâncias psicoativas tem características peculiares quando se considera as abordagens terapêuticas disponíveis para a população dependente geral. Um número menor de mulheres em comparação a homens procura tratamento especializado. Tradicionalmente, os serviços de atenção a dependentes químicos oferecem terapias semelhantes para homens e mulheres, incluindo grupos mistos em alguns serviços.

Objetivo: Discutir os significados psicológicos atribuídos por mulheres dependentes de substâncias psicoativas a fenômenos associados à adesão ao tratamento em um ambulatório universitário especializado. Método: Foi utilizado o método clínico-qualitativo, isto é, uma abordagem caracterizada pelo enfoque tipicamente qualitativo das ciências humanas adaptado ao contexto da saúde. Adotou-se a técnica de entrevista semiestruturada com questões abertas na coleta dos dados, combinada com observação das mulheres entrevistadas. Os dados obtidos foram tratados utilizando análise qualitativa de conteúdo. Resultados: Três categorias de desfecho de tratamento foram identificadas: 1) motivações significativas para buscar e seguir o tratamento proposto; 2) significados simbólicos atribuídos à substância química; 3) representações psicológicas de desmotivação para explicar a dificuldade em aderir ao tratamento.

Conclusões: Nossos achados sugerem que as motivações que levam mulheres dependentes a procurar tratamento são múltiplas, destacando-se o fato de que a substância utilizada passa a ser percebida como algo que traz perdas relevantes e prejudica o exercício adequado do papel feminino nos âmbitos familiar e social. Um acolhimento adequado é considerado fundamental para que a paciente prossiga seu tratamento, compensando o forte prazer físico associado ao uso da substância psicoativa. Descritores: Pesquisa qualitativa, desistência ao tratamento, serviços de saúde da mulher, saúde da mulher, transtornos relacionados ao uso de substâncias, cooperação do paciente. instrumento, avaliação.

${ }^{1}$ MSc in Biomedical Sciences (Mental Health), Universidade Estadual de Campinas (UNICAMP), Campinas, SP, Brazil. ${ }^{2}$ Tenured professor, Department of Medical Psychology and Psychiatry, School of Medical Sciences, UNICAMP. ${ }^{3}$ MD, PhD. Department of Medical Psychology and Psychiatry, School of Medical Sciences, UNICAMP. ${ }^{4}$ RN, PhD. School of Nursing, UNICAMP.

This study was carried out at the Qualitative-Clinical Research Laboratory, Department of Medical Psychology and Psychiatry, Graduate Program of the School of Medical Sciences, Universidade Estadual de Campinas (UNICAMP), Campinas, SP, Brazil.

Financial support: Coordenação de Aperfeiçoamento de Pessoal de Nível Superior (CAPES).

Submitted Jan 13 2011, accepted for publication Aug 24 2011. No conflicts of interest declared concerning the publication of this article.

Suggested citation: Ribeiro DV, Turato ER, Azevedo RCS, Campos CJ. Views of treatment adherence among psychoactive substance-dependent women in the outpatient setting: a qualitative study. Trends Psychiatry Psychother. 2012;34(4):198-206. 


\section{Introduction}

There are significant gender differences in the frequency and psychosocial profile of male and female psychoactive substance abusers. ${ }^{1}$ Fewer women use drugs when compared with men, however a higher percentage of women face quality of life problems associated with drug abuse; in addition, female abusers tend to be younger. The use of stimulants and tranquilizers is more frequent among women, whereas men more frequently present long-term drug abuse histories. Moreover, men tend to continue using the drug, even at advanced ages, whereas older women usually quit or greatly reduce drug use. Conversely, according to a survey conducted in the southern Brazilian state of Rio Grande do Sul, designed to describe the progressive profile of female patients admitted to a psychiatric inpatient service over a 70-year time span, some of the changes observed in the types of mental disorders diagnosed, especially the increased prevalence of alcohol abuse among women, seem to be the result of increased psychosocial tensions and a heavier work load in this population. ${ }^{2}$

Chemical dependence is the result of an encounter between an individual and a psychoactive substance in a certain psycho-socio-cultural context. Drug misuse is a highly complex phenomenon that cannot be reduced to biological components or be understood based solely on characteristics of drug-dependent behaviors or the psychodymanic aspects involved. Rather, drug abuse has to be investigated taking into consideration that all these factors are concomitantly present and simultaneously influence one another. ${ }^{3}$ If, on the one hand, several different conceptions have been put forward for what we now call substance dependence, on the other hand there is a variety of treatment options available. As a result, knowing details about each case, including overall clinical, psychiatric, psychological, and social evaluations, is essential to ensure successful treatment outcomes. Once the medical team is aware of the patient's level of dependence, abstinence symptoms, and social and emotional support network, then the most adequate intervention can be indicated for that individual.

One possible theoretical approach to achieving a better understanding of chemical dependence is psychodynamics. Even though a great number of drugdependent patients receive psychoanalytic therapy, little has been published on the topic in the literature. The scarcity of information was evidenced by Ramos, ${ }^{4}$ who reviewed psychoanalytic contributions in the field of drug dependence in the past 100 years.

The main meanings attributed by Freud to the socalled toxicomanias were already present in his prepsychoanalytic works, i.e., before 1900 . Freud considers masturbation to be the first "toxicomania," namely an "addictive sexual impulse," resulting from changes caused by addictions in general. Masturbation would be an excessive, auto-erotic, narcissism, i.e., the psychic functioning common to all addictive sexual behaviors. ${ }^{5-7}$ In this sense, it is fair to speculate that substancedependent people may want to symbolically preserve a primitive auto-erotic pleasure because they did not manage to adequately develop their sexuality. Another psychoanalytic author, Gianesi, ${ }^{8}$ does not believe in a "toxicomania structure," neither in the possibility to describe one single profile of drug addicts. Rather, each patient would have a particular relationship with the object drug according to their own structure or character. As a result, individuals with a neurotic character would be trying to cope with their already established relationship with castration, in a constant attempt to deny it, escaping while using the drug; individuals with a pervert character, in turn, would use the psychoactive substance as a phallic substitute. Gianesi also describes that patients with a psychotic character would look for a substitute for anything that could not or cannot be symbolized.

Regardless of the type of approach used to treat psychoactive substance dependence, professional practice points toward a certain repressed demand at specialist health care institutions. Indeed, it is easy to understand that these individuals will have greater difficulties dealing with psychological problems, requiring an especially warm welcoming from health care professionals and from society as a whole. ${ }^{9}$

The scientific literature has described non-adherence to health care therapies as a universal phenomenon, regardless of socioeconomic status, ethnic origin, education level, or even disease severity. ${ }^{10}$ Within this scenario, a better understanding of the term "adherence" becomes necessary, in view of some conceptual divergences observed in the literature. First, there is compliance, a term frequently used in the biomedical setting, which sees the patient as the one in charge of following clinical recommendations. This concept does not take into consideration individual factors that may influence treatment success. Adherence, in turn, seems to take the patient's perspective into account, or the fact that the patient is free to follow or ignore medical advice. So, in order to fulfill the goal of complete treatment adherence, it is necessary to consider not only the objective importance of following medical recommendations, but also the symbolic issues evoked by the treatment proposed and their effects on the daily lives of these people. ${ }^{11}$

Among females, non-adherence is even more relevant, so it becomes necessary to understand the 
characteristics of such phenomenon in this small group of women who seek specialist treatment for psychoactive substance abuse. In addition to the different rates of treatment-seeking between men and women, another potential problem is the fact that most health care services offer similar therapies to both male and female addicts, including mixed-sex groups at some facilities. ${ }^{12}$

One previous study conducted with pregnant drug abusers in the United Kingdom reported successful treatment outcomes. The study included multidisciplinary sessions specifically designed for women, always offered at the same clinic, and underscored the importance of staff reliability and a non-judgmental attitude of staff. ${ }^{13}$ In Brazil, a survey carried out with drug-dependent women revealed that specialist health care services specifically directed to women, i.e., those including social work, legal assistance, family interventions, professionals working with self-esteem and body image issues, as well as those offering group therapy sessions, produced more effective or successful results. After 6 months, $66.3 \%$ of the women attending women-only programs were still under treatment, compared with $43.9 \%$ of women attending mixed-sex programs. ${ }^{14}$

Another important factor mentioned in an American study is the fact that women are more likely to talk about relevant psychosocial problems when in a womenonly group. The specific topics covered by the groups, focusing specifically on female health issues, combined with a stronger feeling of comfort to discuss private issues relevant for relapse, in a same-sex setting, may have contributed to the sustained, continuous improvements observed in that study. In addition to the more open and comfortable discussions, a higher degree of mutual understanding and acceptance was also observed in the women-only group. ${ }^{15}$

The objective of the present study was to discuss the views or psychological meanings attributed by women with substance use disorders to their experiences of adherence or non-adherence to treatment at a specialist university outpatient clinic.

\section{Methodology}

\section{The qualitative-clinical method in substance dependence research}

The goal of qualitative research is to give voice to the subject, emphasizing the subjectivity or singularity of marks or traces left by different events in human individuals or groups. So, qualitative methods are typically used in human sciences, which traditionally do not search for causal relationships (cause-effect relationships between elements/events/variables), as originally conceived in natural sciences, but rather for meaning relationships attributed by subjects and by the investigator involved in the study of human phenomena. The interpretative/symbolic character of qualitative research is also underscored, differently from quantitative research, where specific objectives, focuses, and methodological approaches are present. ${ }^{16}$

Because our goal was to achieve a better understanding of personal meanings attributed to different phenomena observed specifically in the health care setting, and considering the clinical experience of the principal investigator, we decided to adopt a qualitative-clinical method. This approach reflects the need for a specific epistemological-methodological construction process, compatible with health care settings (demanding a clinical attitude on the part of the investigator), as a result of the peculiarities of this field, namely, human suffering during the course of disease (demanding an existentialist attitude toward human agony). ${ }^{17}$

Qualitative research applied to health care settings has contributed toward a better understanding of the psychosocial meanings assigned to the use of psychoactive substances. Qualitative investigators share the premise that the realities experienced by people are multiple, which conveys a polysemous aspect to this methodological approach, i.e., the phenomena experienced and/or observed by the individuals lead to different meanings. As a result, the qualitative method works as a tool to help understand the depth, richness, and complexity of human phenomena related to the use of psychoactive substances. ${ }^{18}$

\section{Procedures}

The present study is the result of the insertion of the principal investigator (D.V.A.R.) in a public social work referral center. The Psychoactive Substance Outpatient Clinic (Ambulatório de Substâncias Psicoativas) is part of the psychiatric outpatient services offered by Hospital das Clínicas da Universidade Estadual de Campinas, in Campinas, southeastern Brazil. The clinic primarily serves residents of the municipality of Campinas and surrounding areas in the state of São Paulo. Weekly sessions are held with local residents, whereas patients coming from other states or towns are seen for evaluation and referral. Service is free of charge and very straight-forward. The outpatient population served by the hospital is comprised primarily of adult alcohol, tobacco, or illicit drug abusers/addicts who participate in group therapy sessions and are also individually seen by psychiatry residents for clinical evaluation and to study the possibility of starting pharmacological treatment and overall guidance. 
The present investigation used intentional sampling, i.e., subjects were deliberately chosen according to the goals of the study. The following inclusion criteria were taken into consideration: being a female psychoactive substance-dependent patient according to the diagnostic criteria set forth in the International Classification of Diseases, Tenth Revision (ICD-10) (diagnostic criterion used by the medical team of the service); being enrolled in an outpatient follow-up regimen; being 18 years or older; presenting the necessary emotional, intellectual, and clinical conditions to allow proper data collection via a psychological interview; signing an informed consent form prior to entering the study.

The inclusion criteria mentioned above are few and accurate, eliminating the need for the so-called exclusion criteria, usually present in experimental studies. As a result, a qualitative sample could be set up, at least a priori, disregarding certain biodemographic characteristics of the individuals, more specifically epidemiological variables, e.g., sex, age, marital status, education level, socioeconomic status, occupation/profession, place of birth/origin, religion, history of comorbidities, etc. These characteristics are usually not considered as inclusion or exclusion criteria because they are not valid from the point of view of causal reasoning, typically observed in epidemiological interventions or experimental studies. However, these characteristics will be recorded, and will probably gain meaning when analyzed in relation to interview findings, establishing a meaning relationship as conceived in human/symbolic sciences.

The technique used to determine sample size was the data saturation approach, i.e., the investigator decides to terminate patient selection when the information collected during the interviews becomes redundant. In other words, the investigator consults with his supervisors or peers, informing that the inclusion of more patients/data would add little to the results considering the study objectives. It means considering a sample size large enough to allow information redundancy. ${ }^{19}$

In practice, the principal investigator gained access to a list of women treated at the service between 2001 and 2007, the year when data collection started. At first, women who had dropped out of treatment were identified; those living in Campinas and who had a telephone number available were contacted. Subsequently, all women enrolled in follow-up care were interviewed at the clinic on their regular visit day, with a special time set for the interview.

A semi-structured interview with open questions was used, so as to allow accurate observation and attentive listening to the interviewees. A psychoanalytic attitude was adopted, i.e., the influential presence of the psychic energy of the unconscious was taken into consideration, both while making questions and also while listening to and interpreting subjects' responses. In order to ensure a broad data collection, the following sequence was observed during the interviews: the first part focused on biodemographic characteristics of the subject (personal data); the second part aimed to find out the meanings attributed by patients to the care provided and to the welcoming offered by the specialist outpatient clinic, and also the meanings attributed to drug in the lives of these women and whether they interfere with treatment adherence; finally, the third part focused on observation data regarding both the informant and the interviewer. Interviews were started with a triggering question on treatment-seeking: "Tell me how you decided to seek treatment for drug dependence." All interviews were conducted by the principal investigator. A voice recorder was used to guarantee a complete recording of data.

Sample size was determined and patient selection terminated after 10 subjects had been interviewed. The transcripts of the 10 interviews comprised the corpus of analysis. Material categorization was performed as recommended in the literature, while reading the interview transcripts. ${ }^{20}$

The corpus was analyzed using qualitative content analysis, a subtype of conventional content analysis that follows these steps: 1) after full and literal transcription of voice recordings, repeated, random readings of the corpus are made so that the investigator can grasp the affective tone of the interviews (not much attention is paid to the content of discourse at this moment); 2) the investigator allows core meanings to emerge during the reading of all interviews, establishing associations between what was said and what remained unsaid (scientific truth is invisible to the empirical and immediate reading of reality); 3 ) in theory, those core meanings should scientifically allow an in-depth and continuous revisability of the presuppositions inferred by the authors when designing the project; 4) core meanings resulting from the categorization process and topics for discussion/ interpretation are determined based on stretches of discourse marked by psychological meanings (this stage focuses on the emic perspective, i.e., qualitative data constructed taking into consideration the insider's psychocultural view, trying to avoid the bias of imposing, even if not on purpose, problematics concerned with the investigator); 5) using peer review, meaning categories are methodologically validated with regard to their theoretical content and the number of items adequate to the profile of the intended results; 6) when necessary, new categories can be created and others can be merged, aiming to increase argumentative consistency, find theoretical support from other disciplines, and improve conciseness, objectivity, or lightness of the presentation; 
7) the categories discussed within the group of authors are ready for comparison with other literature results.

The present research project was approved by the Research Ethics Committee of the School of Medical Sciences at Universidade Estadual de Campinas (UNICAMP), Campinas, SP, Brazil. All data collection procedures were conducted according to the guidelines established for identity preservation and non-disclosure of personal information. In this paper, patients are identified using aliases.

\section{Results and discussion}

The women interviewed were aged between 43 and 57 years. Three were dependent on alcohol (one dropout), three on tobacco, one on both alcohol and tobacco (dropout), one on cocaine (dropout), one on crack cocaine (dropout), and one on multiple psychoactive substances. The following categories emerged during data analysis: 1) significant motivations to seek and follow the treatment proposed; 2) symbolic meanings attributed to the substance/drug; 3) psychological representations of lack of motivation to explain difficulties adhering to treatment. Selected topics were discussed borrowing concepts from psychodynamic psychology, commonly used in medical psychology. ${ }^{21}$

The present study was motivated by empirical evidence suggesting that a low number of women sought specialist treatment for psychoactive substance abuse. Such evidence was observed during the ambientation and acculturation phase.

\section{1) Significant motivations to seek and follow the treatment proposed}

Strong motivation is needed to make a woman seek treatment for drug dependence. Examples include phenomena that carry equally strong symbolic meanings from a psychodynamic or sociocultural perspective, e.g., concern with the children, the family, or perceived negative health consequences. Motivation has to be continuous, so that the woman can stay in treatment in the long term. Good and long-lasting relationships with the health care team certainly help patients keep motivated.

(...) I got very sick and they told me that I should come over. Then I started to come, but it took me a long time to quit smoking. (Juciara)

(...) I have to keep sober for him [son], so that I can enjoy his company, as well as my husband's company, and live well in society. (Potira)
(...) [talking about the group] you are welcome, we are here to support you, nobody will criticize or judge you, so that's great. The group just boosts people's spirits. (Jaci)

A qualitative study conducted with African-American women referred that the fear of losing custody of their children is directly related with difficulties adhering to treatment, ${ }^{22}$ as seeking treatment means to publicly admit that you have serious problems with psychoactive substances. At the same time, as shown in the present study and also in that of Cohen et al., ${ }^{23}$ some women indeed start treatment based on so-called external motivations, i.e., based on the fantasy that they will lose their children for legal reasons or as a result of their concern with society's criticism.

We understand that when individuals leave/forget themselves and think of others, interpersonal relationships reorganize their thoughts and behaviors, ultimately making them quit substance abuse. The narcissist, auto-erotic pleasure experience is restructured, and then the other, with his/her eyes and voice, becomes the source of pleasure. Reality emerges, and the same woman who once wanted to live in a delusional world, using a more primitive form of mental functioning, now is able to read and interact with reality, which ends up motivating her attempt to change the state of things. Our patients listed as major sources of motivation for seeking and staying in treatment the anxiety associated with health problems, depressive symptoms, as well as relevant psychosocial losses, e.g. divorce/separation, distance from family members, and losing a job.

These findings are in line with a recent study that showed that the start of treatment among women was primarily motivated by early psychosocial and health complications. They also seek assistance as a result of the severity of their psychiatric problems, which tend to be more evident and severe in women than in men. ${ }^{24}$

It seems that reality imposes itself more quickly to women, maybe because of the supposedly fragile nature of the female body in response to drug effects, or maybe because of their more evident lack of psychological organization. Moreover, this finding suggests that denial of the so-called psychoanalytic "emptiness" or castration through the use of substances does not work well in women. They quickly become depressed or emotionally affected, which then motivates them to seek other ways to deal with their anxieties.

From a different standpoint, we observed that some factors such as acceptance and the group's unconditional support motivate patients to stay in treatment. Previous studies have shown that women would suffer more with stigmas associated with their roles as mothers, more frequently feeling shame or guilt. ${ }^{25}$ It is therefore 
easier to understand how important it is for them to feel welcomed and not judged or criticized during their treatment - a determinant of treatment adherence.

\section{2) Symbolic meanings attributed to the drug}

Some interview stretches suggested that the substance was seen as a source of pleasure and relief within a context of ambivalent feelings regarding the goal of quitting substance abuse on the one hand and a strong bond with the substance on the other. Although this finding has been widely observed in our clinical experience, its manifestation in the female universe of psychoactive substance abuse, with a peculiar and extremely strong affective demand, is especially interesting and deserves mention.

(...) I think that it [smoking cigarettes] made me feel confident. It was there for me in the best and worst of times, right by my side, and then I could cry, tell my secrets, suffer... My cigarette would never tell anything to anyone, it would always be faithful... and suddenly it goes away, so I think it's normal that I miss it. (Jaci)

Whenever something or someone hurt me, I drank because I felt mad at the person. Whenever I felt like telling someone off... I drank in order not to fight. Not to tell the person off. (Janaína)

(...) One of the voices in my head says: "Come on! Drink!" The other says: "No, you know you can't drink." Then the first one says: "Come one, you can have just a little bit." And the other says: "If you have a little bit you won't stop." ... But when I really feel like drinking, I just leave everything behind. (Potira)

At some times, the substance was referred to as the only possible way of obtaining an intense pleasure and/ or a relief of chronic displeasures. These women reported difficulties finding other effective ways of dealing with or ameliorating their suffering.

This point of view is associated with symbolic meanings that can generate ambivalent feelings and thus hinder plans to quit substance use or stay in treatment: dependent women see life as extremely complicated without their psychoactive substances. This close bound with the drug and the absence of other interests in life create a strange affective relationship between the user and the drug - a relationship that affects the patient's will to quit. It is therefore natural that these patients still have ambivalent feelings when they first seek treatment, i.e., they at the same time want to stop using the substance but have expectations to use it again.
When such symbolic meanings are recognized, we come to understand that the use of drugs involves internal phenomena related to psychological development, conscious and unconscious motivations, as well as social, environmental, and educational factors. The widely discussed relationship between psychological dependence and the seduction of addiction on the media and social settings also deserves to be mentioned. According to Fontanella \& Turato, ${ }^{26}$ the onset of substance abuse usually takes place at a stage of discovery, during childhood and adolescence, which conveys a certain innocence. This condition seems to minimize the negative meanings attributed to the substance by the user, who then classifies it as addiction or chemical dependence. It becomes more difficult for patients to question their dependence when they consider it as a source of pleasure or love object.

Conversely, our findings reveal that the use of alcohol and illicit drugs by these women is frequently connected with their wish to get free from bad feelings, e.g., depressive symptoms, victimization, deep loneliness, and family pressure. The women interviewed in our study clearly reported that they used the substance to feel relieved or to forget about their problems. Similar findings were reported in a previous study, which showed that drug users lived in social isolation, usually as a result of sexual traumas followed by difficulties establishing new, adequate interpersonal relationships. ${ }^{27}$

In the first part of our interview (personal data collection), some evidence of the women's experience with the use of psychoactive substances already emerged, mixed with basic personal data covered by the interview questions. Patients were anxious and eager to tell their stories, sharing them with the interviewer, and they spent long amounts of time describing life events marked by loss, physical and sexual violence, and neglect. The literature suggests that childhood victimization increases the risk for drug abuse and sex trading in adult life, and it also makes treatment more difficult. ${ }^{28}$

These events suggest that some women experience an extremely strong psychological emptiness, and raises the need to investigate in detail whether they have themselves been a love object for their parents. Conversely, compensating for this emotional emptiness by using psychoactive substances would be the result of their creation of situations for nurturing themselves alone, without anyone's help.

We also confirmed the importance of offering truly comprehensive and centralized health care. Some women suggested that they would like to receive all the necessary care at one single service, including consultations with other medical specialties. Based on the women's complaints about having to go to other 
services, we speculate that the centralization of all specialties required by female populations could improve treatment adherence in general and adherence to chemical dependence treatment in particular.

Some other authors had already recommended that specialist health care institutions should be prepared to deal with a wide variety of topics related to addiction in women, e.g., victimization, motherhood, psychic functioning, and crime. ${ }^{29}$ Improvements are expected as a result of the incorporation, by medical and psychological therapies, of strategies to deal with issues inherent to the psychocultural universe of women, rather than focusing only on psychoactive substance abuse. ${ }^{30}$

Our interviews also revealed some degree of distress in relation to mixed groups and to group therapy, which focused less on the particular interests of each patient. We therefore infer that same-sex groups, with regular participants, would make these women feel more comfortable in telling their problems. Offering a womenonly therapy group would increase the possibilities of psychological identification among participants. Because this option is not available at the clinic where the study was carried out, we do not have data that could be used for a detailed discussion of the symbolic meanings of this welcoming experience.

\section{3) Psychological representations of lack of motivation to explain difficulties adhering to treatment}

Some factors negatively influenced the adherence of women to treatment of psychoactive substance dependence, including changes in the medical team and participation in mixed-sex groups or those perceived as not very welcoming.

[why she interrupted treatment] (...) I was getting used to that doctor, then once I went there [to the clinic] and it was another doctor. You end up getting sick and tired of it. Of changing all the time, I think that bothers a bit. (Moara)

(...) it's a lot of people, and most of them are men, so I don't feel comfortable talking openly about myself. (Iracema)

We agree with Nóbrega \& Oliveria ${ }^{31}$ in that women need a warm welcoming, free from culturally established judgments and focusing specifically on female selfesteem issues. When trying to understand treatment adherence, analyzing the way how health professionals and patients communicate is a determining factor. When asked about what they considered important in health care, women reported that attention and interest shown by health care professionals was as important as - or even more important than - technical quality. ${ }^{32}$

In the present study, feeling welcome (or not) at the service had a direct influence on treatment adherence. Patients were honest when they informed that they felt well after the visits and that that feeling of well-being motivated them to come back next time. Conversely, those who did not feel well cared for dropped out of treatment, at least for some time. These reports reveal the need to allow women longer amounts of time to talk and share their experiences and anxieties.

Considering that mental functioning is marked by sexual development and by object relationships established, it is fair to suppose that in chemically dependent patients an exaggerated bonding takes place with this particular object (substance). The aim of such strong bonding would be to achieve special pleasure, which in fact would correspond to the search for more primitive pleasures, e.g., those experienced in motherhood. We could even hypothesize - although such a hypothesis would be audacious and difficult to prove that psychoactive substance abusers would psychically feel like orphans, because of the unconscious perception of not having been a love object for their parents. This psychological condition would then lead to a continuous attempt to compensate for that essential feeling of emptiness, e.g., by turning to drastic resources, such as the use of substances with severe mental effects. ${ }^{33}$

Under this perspective, psychoactive substance abusers would need to experience positive relationships in the external world, i.e., they would need to feel loved. Conversely, it is easy to understand their difficulties tolerating changes and frustrations, e.g., a change in the medical team (new separation events reinforcing the primitive and painful feeling of emptiness).

Some limitations of the present study deserve to be mentioned. First and foremost, corpus analysis was based on data collected in one single interview, which gives us a limited view of a specific moment in the individuals' lives. Second, the study was conducted at a university outpatient clinic specializing in the treatment of psychoactive substance users and/or dependent patients, with its own specificities and limitations, which may have had either positive (supervised visits, hospitalbased clinical support, scientific research environment) or negative (frequent change in medical team, physical space constraints that do not allow a higher number of specific groups) impacts on treatment adherence results.

We suggest that future studies continue to investigate populations with the psychosocial profile here described, with a specific focus on the course of treatment and its clinical manifestations. Substance users who have not 
sought specialist treatment, selected among the general population, would be another interesting line of research.

\section{Conclusion}

The motivations that led psychoactive substancedependent women to seek professional help were varied, ranging from factors related to service structure to individual factors that either improved or hindered treatment adherence. In most cases, the cry for help seems to be made when the use of psychoactive substances starts to have negative consequences not thought of originally, or when it leads to significant personal losses. Although similar phenomena are also observed in males, women show a greater concern with social losses and with what people will think of them, and they tend to give more value to aspects such as stigmatization and devaluation by the people surrounding them.

According to the authors' point of view, the main practical applications of the present study are listed below:

1) Theambientation/acculturation phase was considered important for the subsequent performance of a qualitative-clinical study, and is indicated for new studies using the same methodology, especially those assessing psychoactive substance-dependent populations.

2) Observing the specificities of women's universe may make us question the models currently available for the treatment of chemical dependence and help design new models that better meet the needs of female patients.

3) Women greatly value a warm welcoming by health care professionals/service, so this strategy emerges as a way to minimize patients' fears of judgmental attitudes. This can also be used to improve treatment adherence among women.

4) We were able to improve our understanding of the symbolic meanings attributed to the use of drugs by a group of women, which may potentially help professionals working with similar populations think about the internal dynamics of their own patients.

5) We observed that some of the factors associated with welcoming were related with a poorer adherence to treatment, e.g., frequent changes in the medical team or less welcoming therapy groups.

\section{References}

1. Byqvist S. Drug-abusing women in Sweden: marginalization, social exclusion and gender differences. J Psychoactive Drugs. 2006;38:427-40.

2. Gastal FL, Leite SS, Treptow EC, Marini SS, Noal MV, Binz MA, et al. Mental health, women and social change: a progressive institutional profile from 1931 to 2000 . Rev Psiquiatr Rio Gd Sul. 2006;28:245-54.

3. Silveira Filho DX, Gorgulho M, orgs. Dependência: compreensão e assistência às toxicomanias: uma experiência do PROAD. São Paulo: Casa do Psicólogo; 1996.

4. Ramos SP. A psicanálise e os dependentes de substâncias psicoativas: onde está o pai? Rev Bras Psicanal. 2004;38:649-77.

5. Bento VE. Para uma semiologia psicanalítica das toxicomanias: adiç̧ões e paixões tóxicas no Freud prépsicanalítico. Rev Mal-Estar Subj. 2007;7:89-121.

6. Freud S. Sobre o narcisismo: uma introdução. In: Freud S. (1914). Edição Standard Brasileira das Obras Psicológicas Completas de Sigmund Freud. Rio de Janeiro: Imago; 1989. vol. XIV, p. 85-119.

7. Freud S. Três ensaios sobre a teoria da sexualidade. In: Freud S. (1905). Edição Standard Brasileira das Obras Psicológicas Completas de Sigmund Freud. Rio de Janeiro: Imago; 1989. vol. VII, 118-228.

8. Gianesi AP. A toxicomania e o sujeito da psicanálise. Psyche. 2005;9:125-38.

9. Fontanella BJ. Tratamento das toxicomanias: impasses na medicina, tentativas de respostas - dados sobre Campinas [dissertação]. Campinas: Universidade Estadual de Campinas; 1991.

10. Castilho EA, Szwarcwald CL, Brito AM. Fatores associados à interrupção de tratamento anti-retroviral em adultos com AIDS: Rio Grande do Norte, Brasil, 1999-2002. Rev Assoc Med Bras. 2006;52:86-92.

11. Gonçalves H, Costa JS, Menezes AM, Knauth D, Leal OF. Adesão à terapêutica da tuberculose em Pelotas, Rio Grande do Sul: na perspectiva do paciente. Cad Saude Publica. 1999;15:777-87.

12. Osorio AR, Salazar C, McCusker M. Evaluación de un servicio para mujeres que abusan de sustancias psicotrópicas. Rev. Rev Chil Neuro-Psiquiatr. 2001;39:203-10.

13. Hall JL, van Teijlingen ER. A qualitative study of an integrated maternity, drugs and social care service for drug-using women. BMC Pregnancy Childbirth. 2006;6:19.

14. Hochgraf PB. Mulheres farmacodependentes. J Bras Depend Quim. 2001;2(supl 1):34-7.

15. Greenfield SF, Trucco EM, Mchugh RK, Lincoln M, Gallop RJ. The women's recovery group study: a stage I trial of womenfocused group therapy for substance use disorders versus mixed-gender group drug counseling. Drug Alcohol Depend. 2007;90:39-47.

16. Bosi ML, Mercado FJ. Pesquisa qualitativa de serviços de saúde. Petrópolis: Vozes; 2004.

17. Turato ER. Tratado de metodologia da pesquisa clínicoqualitativa: construção teórico-epistemológica, discussão comparada e aplicação nas áreas de saúde e humanas. 4th ed. Petrópolis: Vozes; 2010.

18. Nichter M, Quintero G, Nichter M, Mock J, Shakib S. Qualitative research: contributions to the study of drug use, drug abuse, and drug use( $r$ )-related interventions. Subst Use Misuse. 2004;39:1907-69. 
19. Glaser BG, Strauss AL. The discovery of grounded theory: strategies for qualitative research. New Brunswick: Aldine Transaction; 1999.

20. Minayo MC. O desafio de conhecimento: pesquisa qualitativa em saúde. 10th ed. São Paulo: Hucitec; 2007.

21. Dias OM, Turato ER. Cigarette smokers' views on their habit and the causes of their illness following lung cancer diagnosis: a clinical-qualitative study. Sao Paulo Med J. 2006;124:125-9.

22. MacMaster SA. Experiences with and perceptions of barriers to substance abuse and HIV risk services among African American women who use crack cocaine. J Ethn Subst Abuse. 2005;4:53-75.

23. Cohenm JB, Greenberg R, Uri J, Halpin M, Zweben JE. Women with methamphetamine dependence: research on etiology and treatment. J Psychoactive Drugs. 2007;4(Suppl):347-51.

24. Hernandez-Avila CA, Rounsaville BJ, Kranzler HR. Opioid-, cannabis-, and alcohol-dependent women show more rapid progression to substance abuse treatment. Drug Alcohol Depend. 2004;74:265-72.

25. Passey M, Sheldrake M, Leitch K, Gilmore V. Impact of case management on rural women's quality of life and substance use. Rural Remote Health. 2007;7:710.

26. Fontanella BJ, Campos CJ, Turato ER. Coleta de dados na pesquisa clínico-qualitativa: uso de entrevistas não-dirigidas de questões abertas por profissionais da saúde. Rev Lat Am Enfermagem. 2006;14:812-20.
27. Young AM, Boyd C, Faan RN, Hubbell A. Social isolation and sexual abuse among women who smoke crack. J Psychosoc Nurs Ment Health Serv. 2001;39:12-20.

28. Vaddiparti K, Bogetto J, Callahan C, Abdallah AB, Spitznagel EL, Cottler LB. The effects of childhood trauma on sex trading in substance-using women. Arch Sex Behav. 2006;35:451-9.

29.Knight DK, Hood PE, Logan SM, Chatham LR. Residential treatment for women with dependent children: one agency's approach. 1999;31:339-51.

30. Warner LA, Alegria M, Canino G. Remission from drug dependence symptoms and drug use cessation among women drug users. Arch Gen Psychiatry. 2004;61:1034-41.

31. Nobrega MP, Oliveira EM. Mulheres usuárias de álcool: análise qualitativa. Rev Saude Publica. 2005;5:816-23.

32. Taylor SD. Women offenders and reentry issues. J Psychoactive Drugs. 1986;28:85-93.

33. Bento V. A psicopatologia da drogadicção: uma abordagem psicanalítica. Arq Bras Psicol. 1987;39:41-50.

\section{Correspondence}

Dione Viégas Almeida Ribeiro

Rua Francisco Pereira Coutinho, 111/604, Parque Taquaral

13087-120 - Campinas, SP - Brazil

E-mail: dioneribeiro@hotmail.com 